\title{
Students' Usage of Mobile Learning on Information Technology and Communication Subject for Grade 9 Students
}

\author{
Supparang Ruangvanich \\ Multimedia Technology, Faculty of Science, \\ Chandrakasem Rajabhat University, \\ Bangkok, Thailand \\ +6695-525-9258 \\ supparang.r@chandra.ac.th
}

\author{
Prachyanun Nilsook \\ Vocational Education Technology Research Center, King \\ Mongkut's University of Technology North Bangkok, \\ Bangkok, Thailand \\ +6681-703-7515 \\ prachyanunn@kmutnb.ac.th
}

\begin{abstract}
This research focuses on the usage of mobile learning among Grade 9 students and adopts the structure of a closed-ended and a five-point Likert scale questionnaire. There are thirty respondents from Mahaphabkajadthong Autpatam School. The questionnaires are randomly assigned to students. The results indicate: 1) most of the Grade 9 students are satisfied with mobile learning in terms of appropriate content $($ Mean $=4.70$, S.D. $=0.65)$ 2) the students have benefited from the use of mobile learning in terms of the sound aspect, especially the appropriateness of the song used in the lesson $($ Mean $=4.03$, S.D. $=0.89)$, and 3) the students are satisfied that the lesson could be reviewed at any time (Mean = 4.33, S.D. $=0.66$ ), so teachers and schools should put more energy and effort into developing the mobile learning content.
\end{abstract}

\section{CCS Concepts}

- Human-centered computing $\rightarrow$ Ubiquitous and mobile computing $\rightarrow$ Ubiquitous and mobile computing design and evaluation methods

\section{Keywords}

Mobile Learning; M-Learning, Usage; ICT; Interactive Learning

\section{INTRODUCTION}

Currently, technology for education is a key aspect of education in the information technology era [1]. Learning and teaching in this era would benefit from learning using computers. A teaching system should connect through a computer network or using the Internet [2]. At the present time we are rapidly entering a period of globalization with the advancement of globally connected telecommunications, computer and information technologies.

For this reason, we have moved into an information society. The world will be unified without boundaries with all activities being linked together. The benefits of education will affect the information flow, knowledge, and knowledge seeking.The diffusion of information for learning is quick and easy in many ways [3]. Mobile learning is a learning and teaching management

\footnotetext{
Permission to make digital or hard copies of part or all of this work for personal or classroom use is granted without fee provided that copies are not made or distributed for profit or commercial advantage and that copies bear this notice and the full citation on the first page. Copyrights for third-party components of this work must be honored. For all other uses, contact the Owner/Author.

ICDEL '18, May 26-28, 2018, Beijing, China

(C) 2018 Copyright is held by the owner/author(s).

ACM ISBN 978-1-4503-6431-7/18/05.

DOI: https://doi.org/10.1145/3231848.3231878
}

approach or it involves self-learning with regard to the curriculum which offers content and learning activities through wireless network technology and Internet network technology [4]. Students can study anywhere and at any time via wireless signals that provide services at various points off campus and off site. It is also referred to as Access Points (students and teachers use mobile devices such as notebook computers, portable computers, PDA/PAD phones, Tablet PCs, Cell Phones /Cellular Phones that are capable for connecting to a wireless network for learning and teaching activities or offering access to learning information for students [5].

For such reasons, mobile learning has a key role to play in learning within society, due to the independence of the wireless network. It could access such information at anyplace and at any time; moreover, the number of mobile devices is increasing. In addition, it focuses on providing students with effective learning development [6]. For this reason, researchers have developed interactive learning packages with regard to mobile learning for Information Technology and Communication subjects in the form of interactive learning packages in order to enhance the learning experience of students. Students can learn content at any time, they can enter into discussion with other students, and with teachers. Moreover, they can inquire about problems about learning and teaching or about content. In addition, they could engage in collaborative learning through interactive instructional packages at anytime and anywhere, as well as measure and evaluate their progress through mobile tracking applications. It is possible to check learning outcomes to enhance the learners' characters as a learning person with a love of life-long learning [7].

In order to engage in mobile learning, learners must have a mobile device which can vary in sizes and prices [2]. These mobile devices can be used as learning tools for mobile learning. These are as follows:

1. Notebook computers are portable computers. They can be as good as or superior to a typical desktop computer. They are now small and portable, even though, the price is still quite high.

2. Tablet PCs are portable computers. They are as good as of personal computers but some kind of tablets do not have any keyboard. While they can use handwriting recognition software, they are very expensive.

3. A Personal Digital Assistant (PDA) is a portable device. A personal digital assistant has a processor which is highly capable. It can display up to 65,000 colors, and in addition they can 
process all types of multimedia files. Palm or Microsoft Pocket pcs can be installed with a variety of software.

4. Cellular phones are common cell phones with an emphasis on using voice data and text messaging (SMS). They are limited with low memory and low transfer rates in terms of Internet access via WAP (Wireless Application Protocol) or GPRS (General Packet Radio Service).

5. Smart Phones are high-capacity mobile devices that include the capabilities of both PDAs and cellular phones. They may be smaller than PDAs and larger than cellular phones. The operating system is Symbian or Windows Mobile. They use an Internet browser program and they are used as a multimedia device for effective teaching. The important feature of this device is that it connects to the network using any wireless technology. They have the ability to access the Internet. Each such device is of different sizes, weights, abilities and prices.

\section{Advantages of mobile learning}

1. Students have privacy and are free to choose their own style of learning.

2. There is no time limit and limit in terms of place, which increases the probability of learning.

3. There is more motivation to learn.

4. The use of m-Learning technology changes the learning environment from a teacher-centered one to interacting directly with learners. It encourages more communication between friends and teachers.

5. It receives anonymous information. This makes the students more confident and allows them to be more courageous.

6. It sends information to the teacher. It also distributes the software to all learners.

7. PDAs or mobile phones that are used for m-Learning will reduce digital differences because they are cheaper than computers. It is comfortable and effective in both a learning and a working environment. They are portable devices that encourage learners to engage in active learning and makes them responsible for self-learning.

Disadvantages of mobile learning

1. The size of memory and limited screen size may be an obstacle when it comes to reading data. The keypad is not as fast as a desktop computer keyboard. The machines also lack standards. This aspect would have to be considered when designing the media to be used, such as screen size and screen layout. Some models are vertical and some models are horizontal.

2. The network connection is also quite expensive, while the quality may not be satisfactory.

3. The software is available on the market, but it may not be compatible with portable phones.

4. The price of a good new model is still high, and the device can be stolen easily.

5. A mobile is not stronger in comparison with desktop computers.

6. They may be hard to upgrade, and some models have limited potential.

7. The technology is being developed continuously; as a result, it lacks standardized production when it comes to mobile learning.

8. The market for mobile phones has changed rapidly. Phones can become obsolete quickly.

9. When users connect to a wireless network, the transmission rate is slow.

10. No data security standards exist yet.
In addition, Keough has also identified a number of key disadvantages of mobile learning [8]. Mobile learning depends on the ever-changing technology. Whenever users learn with a mobile, it transforms the contents by mobile learning. Moreover, it is a step into real social learning. Due to the independence of the wireless networks, learners can access content anytime and anywhere. The number of portable computers in use is increasingly rapidly; while the importance of mobile learning is increasing. The focus is now on developing the learner to learn effectively. Thus, learning involving mobile learning is characterized by the interaction of communication for teaching and learning. In addition, it is an alternative in terms of learning management when it comes to teaching in the traditional classroom.

Learning involving the use of mobile devices is characterized by interaction with learners. The designer should develop the interaction involving one-way and two-way communication, so the appropriate interaction design will allow teaching and learning to interact with mobile learning a link between the messenger and the receiver according to the communicative process. The teacher communicates between students and content, between students and activities, between teachers and students, between lessons and students via mobile devices. The concepts of interaction in teaching and learning, mean that the interactions are set as they happen at the same time in the virtual environment on the network.

Moore is an academic who is a specialist in distance education. He identified three forms of interaction that occur in distance learning [9]:

1. Learner-content interaction. This interaction occurs because of the design of the model of the lesson. This interaction is related to content by reflection through questioning, then students select answers from the lessons so that they learn to think, analyze, synthesize and evaluate as part of the learning process.

2. Learner-teacher interaction. This interaction is the communication between the teacher and the learner. The learner will be stimulated by the teacher. The teacher would raise the questions then she and the student would discuss the selected topic. It could take the form of two-way communication. The teacher can provide feedback to the student, including assessing the student's understanding of learning.

3. Learner-learner interaction. This form of interaction is the communication between learner and learner. It can be both synchronized and asynchronized. Interactive communication between students can be one-to-one, in small groups and in large groups.

Swan studied the relationships between interaction and learning in online environments [10]. He found that the effectiveness of learning occurs through the interaction between four types of learning as follows:

1. Interaction with content. This interaction relates to learners who could express themselves intellectually.

2. Interaction with teacher. This interaction relates to learners interacting with the teacher

3. Interaction with classmates. This interaction occurs when learners communicate with their classmates.

4. Interaction with user interface. This is a design for students to interact with lessons.

Students engage with learning system through the mobile learning platform involving wireless technology. They expect to learn with this technology because it is free, and it allows them to participate in the learning activities. Therefore, the learner needs to know how 
to learn. Mobile learning systems will help students to succeed. McLoughlin and Marshall [11] proposed the concept of scaffolding as follow:

1. To support the students.

2. To encourage students to control and self-direct learning.

3. To provide appropriate and timely feedback.

4. To provide a variety of learning methods.

5. To describe the roles and expectations of the learners.

With such support, the interactions in mobile learning are more successful. Nevertheless, the interaction associated with mobile learning requires mobile devices that support collaborative learning. It focuses on technology that enables learners to work together, both inside the classroom and outside it; moreover, it involves wireless communication. In addition, the interaction characteristics and collaborative learning could use technology as tools for supporting interoperability. For example, using wiki as a tool for working, can support collaborative learning, and this elearning tool allows for collaborative writing among learners. Learners can write and edit on wiki. This is a useful tool and is a great way to learn how to write and edit online.

\section{RESEARCH OBJECTIVES}

The aims of this research are as follows:

1. To study the results of learning involving mobile learning in terms of the subject of information technology and communications.

2. To compare the pretest and posttest learning results involving mobile learning in terms of the subject of information technology and communications.

\section{SCOPE OF THE RESEARCH 3.1 Population and Sample}

\subsubsection{Population}

The population is Grade 9 students at Mahaphabkajadthong Autpatam School. The research took place in the first semester of the academic year 2016. The subject is taught in three rooms to one hundred and five students.

\subsubsection{Sample}

The sample was thirty Grade 9 students, with ten students from each room. All students had mobile devices.

\subsection{Variables}

\subsubsection{Independent variable}

The independent variable is the mobile learning package.

\subsubsection{Dependent variable}

The dependent variable is the learning outcomes.

\subsection{Contents}

The contents in this research are lessons in the subject information technology and communication, involving career and technology for grade 9 students, Office of the Basic Education Commission.

\subsection{Instructional Strategy}

An instructional strategy is a high-level plan with regard to how a subject must be taught. This research developed the instructional design strategy that begins with setting up clear goals, determining the actions that must be taken to achieve these goals, and making use of a variety of resources, techniques, and devices to achieve these goals. The researchers determined that the instructional design strategies are of two types; instructional strategy and media strategy, both of which contribute to the effectiveness of a course.

The resources that are used to achieve these goals include the learning devices, presentation patterns, course structure and features, and the type of media used. A good instructional design strategy facilitates the incorporation of practice exercises, interactive elements, simulations, stories, case studies, etc., to facilitate self-paced as well as result-oriented learning. Moreover, the choice of strategy will depend on various factors such as the subject, the audience, and the learning environment.

\section{RESEARCH METHODOLOGY}

This research takes the form of experimental research. The research procedures are as follows:

\subsection{Analysis}

Study papers and research articles are related to the development of mobile learning packages.

\subsection{Design}

Organize research meetings in order to study the content of the basic programming language, to design a learning methodology and to teach activities of the mobile learning unit. Moreover, each content is designed by a storyboard.

\subsection{Develop}

Develop an interactive instruction package that consisted of seven lessons and use tools to develop the mobile learning package with App Inventor 2.

\subsection{Implement}

Distribute the mobile learning package (from the previous step) to fifteen educational technology experts in order to consider the appropriateness of the mobile learning package. This is done by evaluating the interactive teaching package. It was evaluated in terms of three aspects: content structure design of the teaching system, screen design, and technical. The scores added up to a total of 100 points.

\subsection{Evaluate}

The experiment was carried out with the students in the second semester of the academic year 2016. The students volunteered to participate in the experiment. Twelve students studied the mobile learning package in order to consider the ease of use, ease of access and suitability of the activities. The package was tried with the sample of 38 students in the first semester of the academic year 2016, in order to determine the effectiveness of the mobile learning package. The mobile learning package was applied to the target group for the further research.

\section{DESIGN PROCESSES FOR DEVELOPMENT APPLICATION}

App Inventor 2 plays a role in application development for Android devices by using the Web browser. Moreover, it could use a connected mobile device or an emulator. The App Inventor 2 server stores and monitors the project that was created with the App Inventor 2.

In the development of an application, the process can be as follows:

1. The design of the App Inventor 2 works with the application components.

2. The blog of the App Inventor 2 collects blogs of programs that specify what the program will do. The combination 
of the program as seen by the small parts of each section, is brought together in the same way as the assembly of a puzzle.

Application (it is called App) will appear on the mobile device step by step, while adding components to the program. Therefore, it is possible to test the functionality of an application while it is being developed. Once created, the application can be programmed as a package of applications, and produced as a single application. A stand-alone unit can be mounted on a mobile device. If there is no mobile device on the Android operating system the application can be created using an Android emulator. The software works on the computer and acts as a mobile device. The App Inventor 2 environment is supported for Macintosh computers. It can be used with OS X, General Public License (GNU) or Linux operating system and Windows operating system. Many of the popular models for mobile devices on the Android operating system developed applications with App Inventor 2. It can be installed on any mobile device. In addition, it can run on any Android operating system.

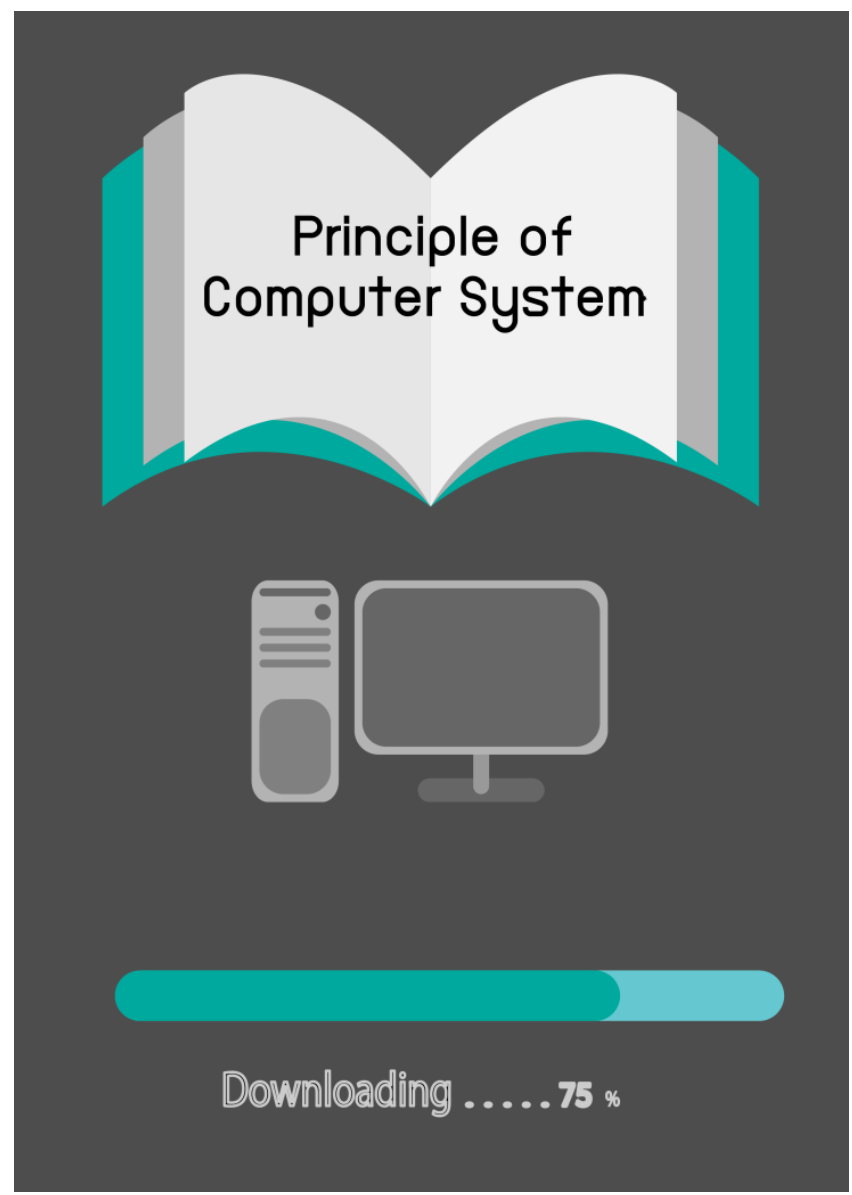

Figure 1. Application Interface

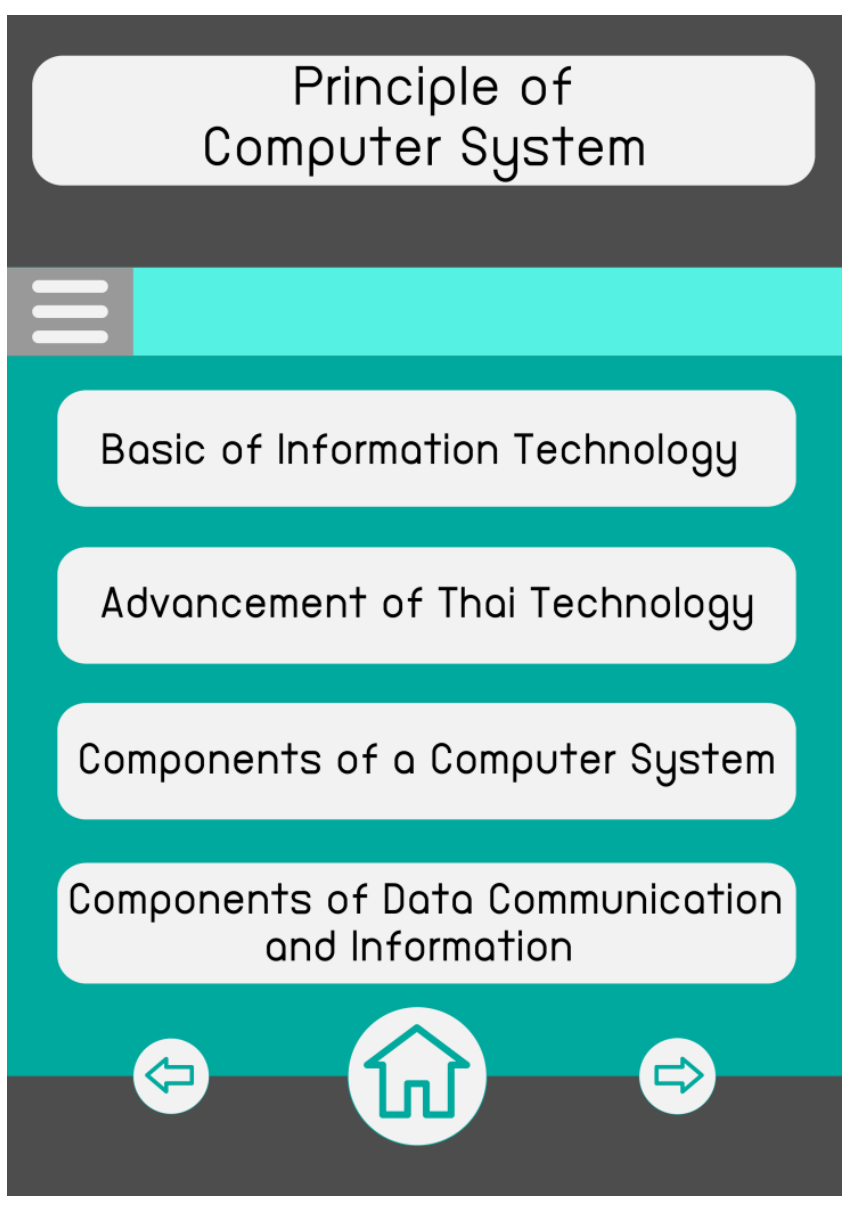

Figure 2. Interface of main menu.

\section{RESEARCH RESULTS}

Table 1. The evaluation of the efficiency of the mobile learning package for Grade 9 students

\begin{tabular}{|c|c|c|c|}
\hline Item & Mean & S.D. & Level \\
\hline \multicolumn{4}{|l|}{ Content } \\
\hline $\begin{array}{l}\text { 1. Content sequencing is a } \\
\text { continuous process and it is easy } \\
\text { to understand. }\end{array}$ & 4.53 & 0.73 & Highest \\
\hline 2. It is clear in describing content. & 4.60 & 0.50 & Highest \\
\hline $\begin{array}{l}\text { 3. Content is interesting and steps in } \\
\text { learning are interesting. }\end{array}$ & 4.40 & 0.72 & High \\
\hline 4. Content is appropriate. & 4.70 & 0.65 & Highest \\
\hline Total average & 4.56 & 0.66 & Highest \\
\hline \multicolumn{4}{|l|}{ Sound } \\
\hline $\begin{array}{l}\text { Accuracy of language used to } \\
\text { describe the content }\end{array}$ & 3.97 & 0.96 & High \\
\hline $\begin{array}{l}\text { 2. Clarity of sound used to describe } \\
\text { the content }\end{array}$ & 3.90 & 0.76 & High \\
\hline $\begin{array}{l}\text { 3. The appropriateness of the song } \\
\text { used in the lesson }\end{array}$ & 4.03 & 0.89 & High \\
\hline $\begin{array}{l}\text { 4. } \begin{array}{l}\text { Consistency of sound level } \\
\text { throughout the lesson }\end{array} \\
\end{array}$ & 3.87 & 0.90 & High \\
\hline $\begin{array}{l}\text { 5. Lectures allowing students to } \\
\text { better understand the content }\end{array}$ & 3.90 & 0.99 & High \\
\hline
\end{tabular}




\begin{tabular}{|l|c|c|c|}
\hline \multicolumn{1}{|c|}{ Item } & Mean & S.D. & Level \\
\hline Total average & $\mathbf{3 . 9 3}$ & $\mathbf{0 . 8 9}$ & High \\
\hline Usage & & & \\
\hline $1 . \quad \begin{array}{l}\text { It encourages students to respond } \\
\text { to the lesson. }\end{array}$ & 4.13 & 0.68 & High \\
\hline $2 . \quad \begin{array}{l}\text { It encourages interaction between } \\
\text { lesson and learner. }\end{array}$ & 4.07 & 0.83 & High \\
\hline $3 . \quad \begin{array}{l}\text { It offers continuous interaction } \\
\text { and is not complicated. }\end{array}$ & 4.17 & 0.91 & High \\
\hline $4 . \quad \begin{array}{l}\text { Learners can control the lesson } \\
\text { by themselves. }\end{array}$ & 3.97 & 0.85 & High \\
\hline $5 . \quad \begin{array}{l}\text { The lesson can be reviewed at } \\
\text { any time. }\end{array}$ & 4.40 & 0.67 & High \\
\hline $6 . \quad \begin{array}{l}\text { The appropriateness of the time } \\
\text { spent throughout the entire } \\
\text { lesson. }\end{array}$ & 4.33 & 0.66 & High \\
\hline Total average & $\mathbf{4 . 1 8}$ & $\mathbf{0 . 7 8}$ & High \\
\hline All average & $\mathbf{4 . 2 0}$ & $\mathbf{0 . 8 2}$ & High \\
\hline
\end{tabular}

Table 1 shows that the evaluation of self-directed learning with mobile learning for Grade 9 students of careers and technology. The research found that the students agreed most highly with an average for the content aspect of 4.56 (S.D. $=0.66$ ). The most commonly agreed upon in terms of appropriate content gave an average of $4.70($ S.D. $=0.65)$. Clarity of content in describing content had an average of 4.60 (S.D. $=0.56$ ), and content sequencing is a continuous process and is easy to understand, had an average of 4.53 (S.D. $=0.73$ ).

Table 1 shows the evaluation of self-directed learning involving mobile learning for Grade 9 students of careers and technology. The research found that the students highly agreed, with average in terms of sound aspect of 3.93 (S.D. $=0.89$ ). The most commonly agreed upon in terms of the appropriateness of the song used in the lesson showed an average of 4.03 (S.D. $=0.89$ ). The accuracy of language used to describe the content had an average of 3.97 (S.D. $=0.96$ ), and the clarity of the sound used to describe the content, averaged 3.90 (S.D. $=0.76)$.

Table 1 shows the evaluation of self-directed learning involving mobile learning for Grade 9 students of careers and technology. The size of the sample is 30 students. The research found that the students highly agreed with an average of usage aspect of 4.18 $($ S.D. $=0.78)$. The lesson review at any time, had an average of 4.40 (S.D. $=0.67)$. The appropriateness of the time spent throughout the entire lesson, showed an average of 4.33 (S.D. $=$ 0.66 ), and the fact that it involves continuous interaction and is not complicated, showed an average of 4.17 (S.D. $=0.91$ ).

Table 2. The comparison of pretest and posttest results in terms of learning achievement for Grade 9 students

\begin{tabular}{|l|c|c|c|c|}
\hline \multicolumn{1}{|c|}{ Test } & $\overline{\boldsymbol{x}}$ & S.D. & t & p \\
\cline { 1 - 3 } Pretest & 9.43 & 2.51 & \multirow{2}{*}{24.77} & $0.00^{*}$ \\
\cline { 1 - 3 } Protest & 16.80 & 1.90 & & \\
\hline
\end{tabular}

$* \mathrm{p}<.05$

From Table 2, we can see that the comparison of pretest and posttest results in terms of the learning achievement of thirty students who learned with mobiles, saw an average mean of 9.43 and a S.D. of 2.51 for pre-test, while the average mean for the post-test was 16.80 , and the S.D. was 1.90 . The post-test was higher than pre-test at level of significance of .05 .

\section{DISCUSSION AND CONCLUSION}

The results with regard to the use of a mobile learning package in information technology and communication subject, careers and technology for grade 9 students, Office of the Basic Education Commission, show that the students most commonly agreed upon the appropriateness of the content, the clarity of the content when describing the content, and that the content sequencing is a continuous process which is easy to understand. The students agreed with regard to the appropriateness of the song used in the lesson, the accuracy of language used to describe the content, and clarity of sound used to describe the content. They also agreed that the lecture helps students better understand the content. This self-directed learning involving mobile learning, with regard to information technology and communication subject, careers and technology for grade 9 students, is an instructional medium that students can study an unlimited number of times. This means that there are no time limits for study and that there are unlimited places. It is easy to engage in the learning process. In addition, mobile learning is also easy to use [12]. The content is clearly arranged and it is easy to understand. The opinion of the Grade 9 students is consistent with that of Mao was studied the satisfaction of undergraduate students with the use of mobile learning [13]. The results indicate that students are satisfied with mobile learning and will use mobile learning in future. Moreover, they have benefited from mobile learning, especially in quickly solving problems encountered in learning, and making better use of learning time [14]. They are satisfied with both the text content and the image content in mobile learning, but the satisfaction with the video content i.e. less clear cut. The item "I am satisfied with the mobile learning resources provided by my university" gets the lowest mean score (2.15), so teachers and universities should put more energy and effort into promoting the quality of mobile learning resources.

\section{ACKNOWLEDGMENTS}

The researchers would like to thank the Faculty of Science, Chandrakasem Rajabhat University for their support and advice and the Vocational Technology Research Center and Innovation and Technology Management, and the Research Center Science and Technology Research Institute, King Mongkut's University of Technology North Bangkok for their continuing support and thank Supaluk Nakhornsri for academic proof reading.

\section{REFERENCES}

[1] Nilsook, P., et al. 2011. A model for the operation of one college one innovation project, the office of vocational education commission. International Journal of Vocational and Technical Education. 3(1), 1-4, 2011.

[2] Piriyasurawong, P. and P. Nilsook. 2010. Web-based Training on Knowledge Management for Vocational Teachers in Thailand. Asian Journal of Distance Education. 8(2), $65-71,2010$.

[3] Nilsook, P. and P. Wannapiroon. 2012. Development of Web-based Training in Collaboration with Convenors of Pilot Colleges under the Office of Vocational Education Commission. Educational Technology Letters. 2(2), pp 4450, 2012.

[4] Palacheewa, P., P. Suwannatthachote, and P. Nilsook. 2013. Critical Issues To Be Concern In Selecting Tools For Teaching High School Computer Project Lesson Using 
Computer- Supported Collaborative Learning. Creative Education. 3, 11-14, 2012 DOI= 10.4236/ce.2012.38B003.

[5] Purnakanishtha, S., P. Suwannatthachote, and P. Nilsook. 2014. Development and Validation of a Problem Solving Skill Test in Robot Programming Using Scaffolding Tools. Open Journal of Social Sciences. 2, 47-53, 2014.

[6] Rodmunkong, P., P. Wannapiroon, and P. Nilsook. 2014. The Challenges of Cloud Computing Management Information System in Academic Work. International Journal of Signal Processing Systems. 2(2), 160-165, 2014 $\mathrm{DOI}=10.12720 / \mathrm{ijsps} .2 .2 .160-165$.

[7] Papattha, C., P. Nilsook, and N. Jeerungsuwan. 2015. Model for Development of Mass Communication Technology Graduates' Desired Characteristics Based on Thai Qualifications Framework for Higher Education. International Journal of Information and Education Technology 5(6), 397-402, 2015.

[8] Keough, M. 2005. 7 reasons why mlearning doesn 't work in the mLearn 2005 4th World conference on mLearning, Mobile technology:The future of learning in your hands. 2005, The future of learning in your hands: Cape Town, South Africa.
[9] Moore, M.G. 1997. Theory of transactional distance, in Theoretical Principles of Distance Education, D. Keegan, Editor. 1997, Routledge. p. 22-38.

[10] Swan, K. 2004. Relationships Between Interactions and Learning In Online Environments, in Sloan-C Editor for Effective Practices in Learning Effectiveness. 2004, Kent State University.

[11] McLoughlin, C. and L. Marshall.2018. Scaffolding:A model for learner support in an online teaching environment. [Febuary 9 2018]. http://cleo.murdoch.edu.au/confs/tlf/tlf2000/mcloughlin2.htm 1.

[12] Saraubon, K., P. Nilsook, and P. Wannapiroon. 2016. System Design of Mobile Augmented Book. International Journal of Interactive Mobile Technologies. 10(1), 52-59, 2016 DOI= http://dx.doi.org/10.3991/ijim.v10i1.5276.

[13] Mao, C. 2014. Research on Undergraduate Students' Usage Satisfaction of Mobile Learning. Creative Education. 5, 614-618, 2014.

[14] Chatwattana, P. and P. Nilsook. 2017. A Web-based Learning System using Project-based Learning and Imagineering. International Journal of Emerging Technologies in Learning. 12(5), 4-22, 2017 DOI= https://doi.org/10.3991/ijet.v12i05.6344. 